\title{
Dismal situation of cardio pulmonary resuscitation knowledge and skills among junior doctors in twin cities of Pakistan
}

\author{
Sanniya Khan Ghauri ${ }^{1}$, Arslaan Javaeed ${ }^{2}$, \\ Faiza Shah ${ }^{3}$, Misbah ul Hasan Ghani ${ }^{4}$
}

\begin{abstract}
Objective: To assess the knowledge, attitude, and practice of cardio pulmonary resuscitation (CPR) among junior doctors in 13 tertiary care hospitals of Rawalpindi and Islamabad.

Methods: A total of 317 junior doctors from 13 tertiary care hospitals in Rawalpindi and Islamabad in Pakistan were included in this cross-sectional study. Data were collected using a 37-item intervieweradministered structured questionnaire by the researchers. Informed consent and ethical approval were secured. Doctors' knowledge, attitude, and practice regarding CPR were presented and compared across the demographic variables (age, gender, CPR training etc.). Data analysis was done using SPSS V 23 at an alpha level of $5 \%$.

Results: Response rate for this study was $87.08 \%$. Abbreviations of BLS, AED, and EMS were known by $94.3 \%, 36.0 \%$, and $41.0 \%$ doctors respectively. No doctor had complete knowledge of CPR. Less than half of the participants knew the proper compression depths. Overall knowledge regarding CPR steps was poor. Out of 31 CPR knowledge, attitude, and practice related questions 21 correct answers were given by two doctors which was the highest score. The mean KAP score was $14.18 \pm 0.15$.

Conclusion: Awareness regarding CPR is essential for all doctors. Many authorities in developed countries are giving CPR training to the general population whereas in Pakistan, many of the doctors never had CPR training. The current study showed the clear majority wants hands-on CPR training. Hospital authorities may find this as an opportunity to improve the knowledege and skills of health workers.
\end{abstract}

KEYWORDS: KAP, CPR, Pakistan, Doctor, BLS.

doi: https://doi.org/10.12669/pjms.35.5.785

How to cite this:

Ghauri SK, Javaeed A, Shah F, Ghani MH. Dismal situation of cardio pulmonary resuscitation knowledge and skills among junior doctors in twin cities of Pakistan. Pak J Med Sci. 2019;35(5):1295-1300. doi: https://doi.org/10.12669/pjms.35.5.785

This is an Open Access article distributed under the terms of the Creative Commons Attribution License (http://creativecommons.org/licenses/by/3.0), which permits unrestricted use, distribution, and reproduction in any medium, provided the original work is properly cited.

1. Sanniya Khan Ghauri, MBBS, MRCEM

Department of Emergency Medicine,

Shifa International Hospital,

Islamabad, Pakistan.

2. Arslaan Javaeed, MBBS, M.Phil, MHPE.

3. Faiza Shah, MBBS.

4. Misbah ul Hasan Ghani. MBBS, MPH.

2-4: Poonch Medical College,

Rawalakot

Azad Kashmir, Pakistan.

Correspondence:

Dr. Sanniya Khan Ghauri, MBBS, MCEM (UK).

Senior Fellow,

Department of Emergency Med.

Shifa International Hospital,

Islamabad, Pakistan.

E-mail: sanniyaghauri89@gmail.com

* Received for Publication:

March 25, 2019

* Accepted for Publication:

\section{INTRODUCTION}

Cardiovascular diseases (CVDs) are the number one cause of death globally. ${ }^{1}$ According to the World Health Organization, about 17.3 million people died from Cardiovascular Diseases (CVDs) in 2008. This represented $30 \%$ of all the global deaths. ${ }^{2}$ Threequarters of all deaths from myocardial infarction occur after cardiac arrest in the community. ${ }^{3}$ This proportion is even higher in people under 55 years of age, in whom $91 \%$ of cardiac arrest deaths occur out of the hospital. ${ }^{3}$ In these conditions, early Cardio Pulmonary Resuscitation (CPR) and early defibrillation might be useful to improve the survival and neurologic outcomes. ${ }^{4}$

Basic life support (BLS) is the foundation for saving lives following cardiac arrest. Fundamental 
aspects of BLS include immediate recognition of sudden cardiac arrest (SCA) and activation of the emergency response system, early cardiopulmonary resuscitation (CPR), and rapid defibrillation with an automated external defibrillator (AED). ${ }^{5}$ All healthcare professionals are expected to have current knowledge of Basic Life Support (BLS) guidelines to revive unresponsive and cardiac arrest patients. ${ }^{6}$

In the present study, we aimed to assess the knowledge, attitude, and practice about BLS among the doctors of 13 tertiary care hospitals in Rawalpindi and Islamabad, Pakistan.

\section{METHODS}

Junior doctors from 13 tertiary care hospitals of Rawalpindi and Islamabad, Pakistan were included in this study as the respondents. The doctors who have been working for less than four years in a hospital were considered as junior doctors. The sample size was calculated using widely used formulae $\mathrm{z}^{2 *} \mathrm{p}(1-\mathrm{p}) / \mathrm{e}^{2}{ }^{1}$. Since the prevalence rate was unknown, $50 \%$ prevalence was considered. At an alpha level of $5 \%$, the required sample size was 384 . In order to include the required samples, the researchers visited these hospitals during the morning, evening and night shifts to recruit as many junior doctors as possible. During the study duration, 364 junior doctors were inducted in the study out which 317 returned the questionnaire with a response rate of $87.08 \%$. The data was collected from April 2018 to October 2018 through a 37 items questionnaire related to demographic characteristics, knowledge, attitude, and practice of CPR among junior doctors. The questionnaire validation was done by two epidemiology professors. Researchers interviewed all the included doctors face to face with the questionnaire. Purpose of the current study was clearly explained to the interviewees. Informed consent was taken from each participant. Ethical approval was secured from Institutional Review Board of Poonch Medical College, Rawalakot, Azad Kashmir, Pakistan.

Statistical Analysis: Frequencies and percentages were used to present the demographic characteristics and CPR knowledge, attitude, and practice related questions and responses. The mean \pm SD number of correct responses to all CPR related questions were presented. The mean number of correct answers were compared between genders, doctor having CPR training (yes/ no), and doctors attended CPR course (yes/ no) by Mann Whitney $\mathrm{U}$ test. The mean number of correct responses were compared across the age groups, time since graduation and time since last CPR training by Kruskal Wallis $\mathrm{H}$ test.

The analysis was performed in 95\% confidence interval using the Statistical Package for Social Science (SPSS), version 23.0 (IBM, Armonk, NY, USA).

\section{RESULTS}

Among the 317 total respondents, 171 (53.9\%) were male and $258(81.4 \%)$ were from age group 23 to 25 years. More than half had $(54.6 \%)$ valid CPR training certificate. (Table-I)

The majority, 299 (94.3\%) knew the abbreviation of 'BLS'. Ninety-eight percent respondents thought BLS training is necessary for the doctors. More than half $(53.0 \%)$ knew the correct compression to ventilation ration which is 30:2. Responses to the 13 CPR knowledge related questions, seven CPR attitude related questions and $11 \mathrm{CPR}$ practice related questions were presented in Table-I, TableII, and Table-III respectively. Mean number of correct answers for all $31 \mathrm{CPR}$ questions for all respondents was $14.18 \pm 0.15$ with a minimum of seven correct answers and a maximum of 21 correct answers.

The mean number of correct answers for all CPR related questions was not statistically significantly different across the demographics. ( $p$ values $>0.05$ ) (Table-V).

Table-I: Demographic characteristics of all respondents.

\begin{tabular}{lcc}
\hline Characteristics & $N$ & $\%$ \\
\hline Age of the doctors & & \\
$23-25$ & 258 & 81.4 \\
$26-30$ & 52 & 16.4 \\
31-34 & 7 & 2.2 \\
Gender of doctors & & \\
$\quad$ Male & 146 & 46.1 \\
Female & 171 & 53.9 \\
Time since graduation & & \\
Last year & 268 & 84.5 \\
Last 2-3 years & 21 & 6.6 \\
Last 4-5 years & 12 & 3.8 \\
$>5$ years & 16 & 5.0 \\
Doctor having valid CPR certificate & 173 & 54.6 \\
Time since last CPR training & & \\
1 year or less & 264 & 83.3 \\
>1 to 2 years & 31 & 9.8 \\
>2 to 3 years & 9 & 2.8 \\
>3 to 4 years & 13 & 4.1 \\
Doctors attended CPR course & 226 & 71.3 \\
\hline
\end{tabular}


Table-II: Answers to CPR knowledge related questions.

\begin{tabular}{|c|c|c|c|}
\hline Questions & Responses & $N$ & $\%$ \\
\hline 1. What is the abbreviation of "BLS"? & $\begin{array}{l}\text { a) Best Life Support } \\
\text { b) Basic Life Support } \\
\text { c) Basic Lung Support } \\
\text { d) Basic Life Services }\end{array}$ & $\begin{array}{c}11 \\
299 \\
3 \\
4\end{array}$ & $\begin{array}{c}3.5 \\
94.3 \\
0.9 \\
1.3\end{array}$ \\
\hline $\begin{array}{l}\text { 2. When you find someone } \\
\text { unresponsive in the middle of the road, } \\
\text { what will be your first response? }\end{array}$ & $\begin{array}{l}\text { a) Open airway } \\
\text { b) Start chest compression } \\
\text { c) Look for safety } \\
\text { d) Give two breathings }\end{array}$ & $\begin{array}{c}91 \\
33 \\
190 \\
3\end{array}$ & $\begin{array}{c}28.7 \\
10.4 \\
59.9 \\
0.9\end{array}$ \\
\hline $\begin{array}{l}\text { 3. If you confirm somebody is not } \\
\text { responding to you even after shaking } \\
\text { and shouting at him, what will be your } \\
\text { immediate action? }\end{array}$ & $\begin{array}{l}\text { a) Start CPR } \\
\text { b) Activate EMS } \\
\text { c) Put him in recovery position } \\
\text { d) Observe }\end{array}$ & $\begin{array}{c}153 \\
82 \\
75 \\
7\end{array}$ & $\begin{array}{c}48.3 \\
25.9 \\
23.7 \\
2.2\end{array}$ \\
\hline $\begin{array}{l}\text { 4. What is the location for chest } \\
\text { compression? }\end{array}$ & $\begin{array}{l}\text { a) Left side of the chest } \\
\text { b) Right side of the chest } \\
\text { c) Centre of the chest on lower half of breast bone } \\
\text { d) Xiphisternum }\end{array}$ & $\begin{array}{c}29 \\
8 \\
211 \\
69\end{array}$ & $\begin{array}{l}9.1 \\
2.5 \\
66.6 \\
21.8\end{array}$ \\
\hline $\begin{array}{l}\text { 5. What is the location for chest } \\
\text { compression in infants? }\end{array}$ & $\begin{array}{l}\text { a) One finger breadth below the nipple line } \\
\text { b) At the intermammary line } \\
\text { c) One finger breadth above the nipple line } \\
\text { d) At Xiphisternum }\end{array}$ & $\begin{array}{c}162 \\
39 \\
31 \\
85\end{array}$ & $\begin{array}{c}51.1 \\
12.3 \\
9.8 \\
26.8\end{array}$ \\
\hline $\begin{array}{l}\text { 6. How do you give rescue breathing in } \\
\text { infants? a }\end{array}$ & $\begin{array}{l}\text { a) Mouth-to-mouth with nose pinched } \\
\text { b) Mouth-to-mouth and nose } \\
\text { c) Mouth-to-nose only } \\
\text { d) Mouth-to-mouth without nose pinched }\end{array}$ & $\begin{array}{l}113 \\
98 \\
19 \\
87\end{array}$ & $\begin{array}{c}35.6 \\
30.9 \\
6.0 \\
27.4\end{array}$ \\
\hline $\begin{array}{l}\text { 7. Depth of compression in adults } \\
\text { during CPR }\end{array}$ & $\begin{array}{l}\text { a) At least } 2 \text { inches } \\
\text { b) } 2^{1 / 2}-3 \text { inches } \\
\text { c) } 1-1^{1 / 2} \text { inches } \\
\text { d) } 1 \frac{1 / 2 \text { inch }}{}\end{array}$ & $\begin{array}{c}123 \\
141 \\
42 \\
11\end{array}$ & $\begin{array}{c}38.8 \\
44.5 \\
13.2 \\
3.5\end{array}$ \\
\hline $\begin{array}{l}\text { 8. Depth of compression in Children } \\
\text { during CPR }\end{array}$ & $\begin{array}{l}\text { a) } 2 \text { inches } \\
\text { b) } 2-2^{1 / 2} \text { inches } \\
\text { c) } 1-1 \frac{1 / 2}{\text { inches }} \\
\text { d) } 1 / 2-1 \text { inch }\end{array}$ & $\begin{array}{c}66 \\
45 \\
107 \\
99\end{array}$ & $\begin{array}{l}20.8 \\
14.2 \\
33.8 \\
31.2\end{array}$ \\
\hline $\begin{array}{l}\text { 9. Depth of compression in neonates } \\
\text { during CPR }\end{array}$ & $\begin{array}{l}\text { a) } 1 \frac{1 / 2-2 \text { inches }}{\text { b) } 2-2 \frac{1}{2}} \\
\text { c) } 1 \text { inch } \\
\text { d) approximately } 1 \frac{1 / 2}{2} \text { inch }\end{array}$ & $\begin{array}{c}64 \\
41 \\
138 \\
74\end{array}$ & $\begin{array}{l}20.2 \\
12.9 \\
43.5 \\
23.3\end{array}$ \\
\hline $\begin{array}{l}\text { 10. Rate of chest compression in adult } \\
\text { and Children during CPR }\end{array}$ & $\begin{array}{l}\text { a) at least } 100 / \mathrm{min} \\
\text { b) approximately } 100 / \mathrm{min} \\
\text { c) } 80 / \mathrm{min} \\
\text { d) } 120 / \mathrm{min}\end{array}$ & $\begin{array}{l}137 \\
81 \\
60 \\
39\end{array}$ & $\begin{array}{l}43.2 \\
25.6 \\
18.9 \\
12.3\end{array}$ \\
\hline $\begin{array}{l}\text { 11. What does abbreviation AED stands } \\
\text { for? }\end{array}$ & $\begin{array}{l}\text { a) Automated External Defibrillator } \\
\text { b) Automated Electrical Defibrillator } \\
\text { c) Advanced Electrical Defibrillator } \\
\text { d) Advanced External Defibrillator }\end{array}$ & $\begin{array}{c}114 \\
144 \\
40 \\
19\end{array}$ & $\begin{array}{c}36.0 \\
45.4 \\
12.6 \\
6.0\end{array}$ \\
\hline $\begin{array}{l}\text { 12. What does abbreviation EMS stands } \\
\text { for? }\end{array}$ & $\begin{array}{l}\text { a) Effective Medical Services } \\
\text { b) Emergency Management Services } \\
\text { c) Emergency Medical Services } \\
\text { d) External Medical Support }\end{array}$ & $\begin{array}{c}17 \\
152 \\
130 \\
18\end{array}$ & $\begin{array}{c}5.4 \\
47.9 \\
41.0 \\
5.7\end{array}$ \\
\hline $\begin{array}{l}\text { 13. If you and your friend are having } \\
\text { food in a canteen and suddenly your } \\
\text { friend starts expressing symptoms of } \\
\text { choking but responsive, what will be } \\
\text { your first response? }\end{array}$ & $\begin{array}{l}\text { a) Give abdominal thrusts } \\
\text { b) Give chest compression } \\
\text { c) Confirm foreign body aspiration by talking to him } \\
\text { d) Give back blows }\end{array}$ & $\begin{array}{c}121 \\
26 \\
61 \\
109\end{array}$ & $\begin{array}{c}38.2 \\
8.2 \\
19.2 \\
34.4\end{array}$ \\
\hline
\end{tabular}


Sanniya Khan Ghauri et al.

Table-III: Answers to CPR attitude related questions.

\begin{tabular}{|c|c|c|c|}
\hline Questions & Responses & $N$ & $\%$ \\
\hline 14. Do you think BLS is necessary? & $\begin{array}{l}\text { Yes } \\
\text { No } \\
\text { Not sure }\end{array}$ & $\begin{array}{c}310 \\
5 \\
2\end{array}$ & $\begin{array}{l}97.8 \\
1.6 \\
0.6\end{array}$ \\
\hline 15. If yes, how necessary it is? & $\begin{array}{l}\text { Very much important } \\
\text { Important }\end{array}$ & $\begin{array}{c}273 \\
44\end{array}$ & $\begin{array}{l}86.1 \\
13.9\end{array}$ \\
\hline 16. Have you ever voluntarily performed BLS? & $\begin{array}{l}\text { Yes } \\
\text { No } \\
\text { Performed but not voluntarily }\end{array}$ & $\begin{array}{c}147 \\
144 \\
26\end{array}$ & $\begin{array}{c}46.4 \\
45.4 \\
8.2\end{array}$ \\
\hline $\begin{array}{l}\text { 17. Would you perform mouth to mouth } \\
\text { ventilation for person of same gender? }\end{array}$ & $\begin{array}{l}\text { Yes } \\
\text { No } \\
\text { Hesitant }\end{array}$ & $\begin{array}{c}188 \\
71 \\
58\end{array}$ & $\begin{array}{l}59.3 \\
22.4 \\
18.3\end{array}$ \\
\hline $\begin{array}{l}\text { 18. Would you perform mouth to mouth } \\
\text { ventilation for person of opposite gender? }\end{array}$ & $\begin{array}{l}\text { Yes } \\
\text { No } \\
\text { Hesitant }\end{array}$ & $\begin{array}{l}126 \\
97 \\
94\end{array}$ & $\begin{array}{l}39.7 \\
30.6 \\
29.7\end{array}$ \\
\hline $\begin{array}{l}\text { 19. Would you like to undergo BLS training in } \\
\text { a workshop / contre with hands on practice } \\
\text { under supervision? }\end{array}$ & $\begin{array}{l}\text { Yes } \\
\text { No } \\
\text { Not sure }\end{array}$ & $\begin{array}{c}288 \\
27 \\
2\end{array}$ & $\begin{array}{c}90.9 \\
8.5 \\
0.6\end{array}$ \\
\hline $\begin{array}{l}\text { 20. Do you think that BLS training should be a } \\
\text { part of your curriculum? }\end{array}$ & $\begin{array}{l}\text { Yes } \\
\text { No } \\
\text { Not sure }\end{array}$ & $\begin{array}{c}301 \\
8 \\
8\end{array}$ & $\begin{array}{c}95.0 \\
2.5 \\
2.5\end{array}$ \\
\hline
\end{tabular}

\section{DISCUSSION}

No doctor could give 100 percent the current answer according to our study. The highest percentage of correct answer given by a doctor was $68 \%$. This study finding goes in line with a previous Indian study which included doctors, other health workers, and medical students. ${ }^{8}$ Knowledge regarding infant and children CPR in comparison with the adult CPR was shown to be poorer in this study (Table-II). This might be due to the overall prevalence of children cardiac arrest cases being lower than the adult cardiac arrest cases. ${ }^{9}$ Only $54.6 \%$ of doctors had valid CPR certificate in 13 tertiary care hospitals in Pakistan, whereas a study revealed $99 \%$ of the medical students received CPR training in UK. ${ }^{10}$

Interestingly, a fewer percentage of doctors would perform mouth to mouth breathing on the opposite gender $(39.7 \%)$ compared to the same gender (59.3\%) (Table-III). Gender based barriers still exist in the health care provision in Pakistan. ${ }^{11}$ The clear majority wanted to get handson BLS training and suggested BLS training to be included in the medical curriculum. This study encourages medical educationists to look at this matter. Because, trained doctors show better CPR related knowledge, attitude, and practice than the untrained doctors. ${ }^{12,13}$
This study showed the duration of medical practice improves knowledge, attitude, and practice score of CPR although not at a statistically significant level (Table-V). Similar and comparable findings were shown by a Malaysian study. ${ }^{14}$

Limitation of the study: The study was crosssectional in nature therefore causality cannot be established. Data were only collected from the tertiary hospitals, which may not represent all the doctors of the country. Only the doctors were included in this study whereas CPR knowledge is essential for all the health workers. Awareness regarding ACLS protocol was not studied.

\section{CONCLUSION}

It is unacceptable to work in a hospital as a doctor without knowing how to perform a basic lifesaving procedure like CPR. The current study raises question about how to improve the knowledge, attitude and, practice among the doctors who never had CPR training. Despite showing an overall poor knowledge most of the participants wanted to perfect the CPR steps. Hospitals should provide enough resources to ensure all its health workers learn and relearn BLS protocols.

Recommendation: This study recommends further studies to assess BLS and ACLS awareness among 
Table-IV: Answers to CPR practice related questions.

\begin{tabular}{|c|c|c|c|}
\hline Questions & Responses & $N$ & $\%$ \\
\hline $\begin{array}{l}\text { 21. Which of the following is } \\
\text { not included in the } 5 \text { links in } \\
\text { the adult Chain of Survival? }\end{array}$ & $\begin{array}{l}\text { a. Early CPR } \\
\text { b. Integrated post cardiac arrest care } \\
\text { c. Advanced airway placement } \\
\text { d. Rapid defibrillation }\end{array}$ & $\begin{array}{l}50 \\
99 \\
74 \\
94\end{array}$ & $\begin{array}{l}15.8 \\
31.2 \\
23.3 \\
29.7\end{array}$ \\
\hline $\begin{array}{l}\text { 22. How often should rescuers } \\
\text { switch roles when performing } \\
\text { 2-rescuer CPR? }\end{array}$ & $\begin{array}{l}\text { a. After each cycle } \\
\text { b. After } 2 \text { cycles } \\
\text { c. After } 5 \text { cycles }\end{array}$ & $\begin{array}{c}75 \\
157 \\
85\end{array}$ & $\begin{array}{l}23.7 \\
49.5 \\
26.8\end{array}$ \\
\hline \multirow[t]{2}{*}{$\begin{array}{l}\text { 23. The initial Basic Life } \\
\text { Support (BLS) steps for adults } \\
\text { are: }\end{array}$} & $\begin{array}{l}\text { a. Assess the victim, give } 2 \text { rescue breaths, defibrillate, } \\
\text { start CPR } \\
\text { b. Assess the victim, activate EMS \& get AED, check pulse, }\end{array}$ & $\begin{array}{l}36 \\
151\end{array}$ & 11.4 \\
\hline & $\begin{array}{l}\text { c. Check pulse, give rescue breaths, assess the victim, } \\
\text { defibrillate } \\
\text { d. Assess the victim, start CPR, give } 2 \text { rescue breaths, } \\
\text { defibrillate }\end{array}$ & 39 & 12.3 \\
\hline $\begin{array}{l}\text { 24. Where should you attempt } \\
\text { to perform a pulse check in } \\
\text { adult? }\end{array}$ & $\begin{array}{l}\text { a. Carotid } \\
\text { b. Brachial } \\
\text { c. Ulnar } \\
\text { d. Temporal }\end{array}$ & $\begin{array}{c}241 \\
28 \\
44 \\
4\end{array}$ & $\begin{array}{c}76.0 \\
8.8 \\
13.9 \\
1.3\end{array}$ \\
\hline $\begin{array}{l}\text { 25. The compression to } \\
\text { ventilation ratio for the lone } \\
\text { rescuer giving CPR to victims } \\
\text { of ANY age is: }\end{array}$ & $\begin{array}{l}\text { a. } 15: 1 \\
\text { b. } 15: 2 \\
\text { c. } 30: 1 \\
\text { d. } 30: 2\end{array}$ & $\begin{array}{c}44 \\
64 \\
41 \\
168\end{array}$ & $\begin{array}{l}13.9 \\
20.2 \\
12.9 \\
53.0\end{array}$ \\
\hline \multirow[t]{4}{*}{$\begin{array}{l}\text { 26. The proper steps for } \\
\text { operating an AED are: }\end{array}$} & $\begin{array}{l}\text { a. On the AED, attach electrode pads, shock the patient, } \\
\text { analyze the rhythm }\end{array}$ & 35 & 11.0 \\
\hline & $\begin{array}{l}\text { b. On the AED, attach electrode pads, analyze the rhythm, } \\
\text { clear the patient, deliver shock }\end{array}$ & 202 & 63.7 \\
\hline & $\begin{array}{l}\text { c. Attach electrode pads, check pulse, shock patient, } \\
\text { analyze rhythm }\end{array}$ & 42 & 13.2 \\
\hline & $\begin{array}{l}\text { d. Check pulse, attach electrode pads, analyze rhythm, } \\
\text { shock patient. }\end{array}$ & 38 & 12.0 \\
\hline \multirow{4}{*}{$\begin{array}{l}\text { 27. The } 2010 \text { AHA Guidelines } \\
\text { for CPR recommended BLS } \\
\text { sequence of steps are: }\end{array}$} & a. Chest compressions, Airway, breathing & 69 & 21.8 \\
\hline & b. Airway, Breathing, Check Pulse & 91 & 28.7 \\
\hline & c. Airway, Breathing, Chest Compressions & 135 & 42.6 \\
\hline & d. Chest compression, Airway placement, Breathing & & \\
\hline \multirow{3}{*}{$\begin{array}{l}\text { 28. Which of the following is } \\
\text { not a sign of severity of airway } \\
\text { obstruction? }\end{array}$} & a. Poor air exchange & 83 & 26.2 \\
\hline & b. High-pitched noise while inhaling & 63 & 19.9 \\
\hline & $\begin{array}{l}\text { c. Unable to cry } \\
\text { d. May wheeze between coughs }\end{array}$ & $\begin{array}{l}76 \\
95\end{array}$ & $\begin{array}{l}24.0 \\
30.0\end{array}$ \\
\hline \multirow{4}{*}{$\begin{array}{l}\text { 29. In an adult with an } \\
\text { advanced airway in place } \\
\text { during 2-rescuer CPR, breaths } \\
\text { should be administered how } \\
\text { often? }\end{array}$} & a. Every 5 seconds & 76 & 24.0 \\
\hline & b. Every 5-6 seconds & 113 & 35.6 \\
\hline & c. Every 6-8 seconds & 70 & 22.1 \\
\hline & d. Every $10-12$ seconds & 58 & 18.3 \\
\hline \multirow{4}{*}{$\begin{array}{l}\text { 30. The critical characteristics } \\
\text { of high-quality CPR include } \\
\text { which of the following? }\end{array}$} & $\begin{array}{l}\text { a. Starting chest compressions within } 10 \text { seconds of } \\
\text { recognition of cardiac arrest }\end{array}$ & 47 & 14.8 \\
\hline & b. Push hard, push fast & 40 & 12.6 \\
\hline & c. Minimize interruptions & 38 & 12.0 \\
\hline & d. All of the above & 192 & 60.6 \\
\hline \multirow{2}{*}{$\begin{array}{l}\text { 31. Have you ever performed } \\
\text { a CPR? }\end{array}$} & Yes & 229 & 72.2 \\
\hline & No & 88 & 27.8 \\
\hline
\end{tabular}


Table-V: Number of correct answers across the studied demographic characteristics.

\begin{tabular}{|c|c|c|}
\hline Characteristics & $\begin{array}{c}\text { KAP score } \\
\text { Mean } \pm S D\end{array}$ & $p$-value \\
\hline $\begin{array}{l}\text { Age of the doctors } \\
23-25 \\
26-30 \\
31-34\end{array}$ & $\begin{array}{l}14.04 \pm 2.78 \\
14.65 \pm 2.52 \\
15.57 \pm 3.21\end{array}$ & 0.211 \\
\hline $\begin{array}{l}\text { Gender of doctors } \\
\text { Male } \\
\text { Female }\end{array}$ & $\begin{array}{l}14.38 \pm 2.64 \\
14.01 \pm 2.85\end{array}$ & 0.244 \\
\hline $\begin{array}{l}\text { Time since graduation } \\
\text { Last year } \\
\text { Last } 2-3 \text { years } \\
\text { Last } 4-5 \text { years } \\
>5 \text { years }\end{array}$ & $\begin{array}{l}14.07 \pm 2.82 \\
14.48 \pm 2.50 \\
15.42 \pm 2.87 \\
14.69 \pm 1.54\end{array}$ & 0.376 \\
\hline $\begin{array}{l}\text { Doctor having valid CPR } \\
\text { certificate } \\
\text { Yes } \\
\text { No }\end{array}$ & $\begin{array}{l}14.36 \pm 2.61 \\
13.95 \pm 2.91\end{array}$ & 0.148 \\
\hline $\begin{array}{l}\text { Time since last CPR training } \\
1 \text { year or less } \\
>1 \text { to } 2 \text { years } \\
>2 \text { to } 3 \text { years } \\
>3 \text { to } 4 \text { years }\end{array}$ & $\begin{array}{l}14.26 \pm 2.67 \\
14.10 \pm 2.86 \\
11.22 \pm 3.19 \\
14.69 \pm 3.12\end{array}$ & 0.090 \\
\hline $\begin{array}{l}\text { Doctors attended CPR course } \\
\text { Yes } \\
\text { No }\end{array}$ & $\begin{array}{l}14.07 \pm 2.51 \\
14.44 \pm 3.30\end{array}$ & 0.200 \\
\hline
\end{tabular}

all health workers of the country. This study also encourages the hospitals to provide mandatory $\mathrm{CPR}$ training to the health workers at free of cost.

Conflict of Interest: None.

Funding: None.

\section{REFERENCES}

1. Nag T, Ghosh A. Cardiovascular disease risk factors in Asian Indian population: a systematic review. J Cardiovas Disease Res. 2013;4(4):222-228.

2. World Health Organization. World health statistics 2010. World Health Organization; 2010.

3. Norris RM. Fatality outside hospital from acute coronary events in three British health districts, 1994-5. Bmj. 1998;316(7137):1065.

4. Rubeen R, Zareen N, Khan F, Rattan S, Moiz M, Nousheen N. Awareness and Practice Of Basic Life Support Among Doctors In Civil Hospital Karachi. Medical channel. 2013;19(1).
5. Berg RA, Hemphill R, Abella BS, Aufderheide TP, Cave DM, Hazinski MF, et al. Part 5: Adult basic life support: 2010 American Heart Association guidelines for cardiopulmonary resuscitation and emergency cardiovascular care. Circulation. 2010;122(18_ suppl_3):S685-705.

6. Nambiar M, Nedungalaparambil NM, Aslesh OP. Is current training in basic and advanced cardiac life support (BLS \& ACLS) effective? A study of BLS \& ACLS knowledge amongst healthcare professionals of North-Kerala. World J Emerg Med. 2016;7(4):263.

7. Kar SS, Ramalingam A. Is 30 the magic number? Issues in sample size estimation. Nat J Commun Med. 2013;4(1):175-179.

8. Chandrasekaran S, Kumar S, Bhat SA. Awareness of basic life support among medical, dental, nursing students and doctors. Ind J Anaesthesia. 2010;54(2):121.

9. Meyer L, Stubbs B, Fahrenbruch C, Maeda C, Harmon K, Eisenberg $\mathrm{M}$, et al. Incidence, causes, and survival trends from cardiovascular-related sudden cardiac arrest in children and young adults 0 to 35 years of age: A 30-year review. Circulation. 2012;126(11):1363-1372.

10. Graham CA, Scollon D. Cardiopulmonary resuscitation training for undergraduate medical students: A five-year study. Med Educ. 2002;36(3):296-298.

11. Mumtaz Z, Salway SM. Gender, pregnancy and the uptake of antenatal care services in Pakistan. Sociol Health \& illness. 2007;29(1):1-26

12. Yunus M, Mishra A, Karim HM, Raphael V, Ahmed G, Myrthong CE. Knowledge, attitude and practice of basic life support among junior doctors and students in a tertiary care medical institute. Int J Res Med Sci. 2015;3(12):3644

13. Passali C, Pantazopoulos I, Dontas I, Patsaki A, Barouxis D, Troupis G. Evaluation of nurses' and doctors' knowledge of basic \& advanced life support resuscitation guidelines. Nurse Educ Pract. 2011;11(6):365-369.

14. Chew KS, Hashairi FM, Zarina ZI, Farid AS, Yazid MA, Hisamudddin NA. A survey on the knowledge, attitude and confidence level of adult cardiopulmonary resuscitation among junior doctors in Hospital Universiti Sains Malaysia and Hospital Raja Perempuan Zainab II, Kota Bharu, Kelantan, Malaysia. Med J Malaysia. 2011;66(1):56-59.

\section{Authors' Contributions:}

SKG, AJ \& FS: Worked on the concept and design of the study.

MHG, FZ: Collected the data.

AJ: Analyzed the data.

SKG: Approved the final version to be published. 